\title{
Development of Home Electrical Power Control System Using RLC Circuits on Electronic Skills Learning
}

\author{
$1^{\text {st }}$ Puji Hariyati Winingsih ${ }^{1}, 1^{\text {st }}$ Handoyo Saputro $^{2}, 1^{\text {st }}$ Pinaka Elda Swastika ${ }^{3}$ \\ \{hansputra13@yahoo.com², jfisika_ust@yahoo.co.id\} \\ Sarjanawiyata Tamansiswa University, Indonesia ${ }^{2}$
}

\begin{abstract}
Indonesia's strong economic growth is expected to continue, thus increasing electricity consumption to reach 491 Tera Watt hours (TWh) in 2030. Significant electricity savings can be obtained by increasing the electrical energy efficiency of homes. The aim of this study is to design a household electrical control system (KENDIL) by using the RLC circuit to reduce the flow in order to achieve more efficient home electricity distribution. The Data collection was carried out at Wisma Kertonegaran as a residential house consisting of 50 rooms. After using KENDIL, The PLN electricity bills per month was decreased from Rp. 176,601.82 / kwh to Rp. 107,294.85 / kwh. It can save electricity bill costs by $60 \%$. This device is an application of electronic skills courses.
\end{abstract}

Keywords: Control, electricity, RLC, power, electronic skills.

\section{Introduction}

Indonesia's important role in global energy markets continues to increase. Indonesia remains the largest energy consumer in Southeast Asia, which is $36 \%$ of the region's energy needs and uses almost as much energy as Thailand, Malaysia and Singapore. Rapid economic growth is driving a sharp increase in electricity demand. Between 2000 and 2015, Indonesia's GDP doubled and electricity demand increased by $150 \%$ [1].

Indonesia's strong economic growth is expected to continue, thus increasing electricity consumption to reach 491 Tera Watt hours (TWh) in 2030. It is estimated that power plant capacity needs to increase by 4.1 gigawatts $(\mathrm{GW})$ per year, of which $50 \%$ of the total installed capacity is new is a coal power plant [2]. As GDP growth, the need for increased comfort of life and human movement increases the need for electricity.

Significant electricity savings can be obtained by increasing the efficiency of home electricity. For example, switching to using an LED (light emitting diodes), which is more efficient. If the trend of using LED lights continues, Indonesia's electricity customers are estimated can save USD 560 million per year in 2030 [3]. Other efforts were also carried out, for example by the existence of a home electricity monitoring system as the previous study said that the House Electricity Monitoring System (SMLR) was able to help users monitor and control the electrical device at home and can reduce excessive electricity usage with electricity savings $25 \%$ [4].

Power is the energy expended to do the work. In an electrical power system, power is the amount of energy used to do work as shown in Figure 1. 
While, the illustration of voltage and current can be explained in Figure 2. The amount of work is e.i.t Joule which is consists of positive parts and negative parts. If the positive parts are as big as the negative parts, this means that if the two parts are added up, it will be zero. To explain this, it is calculated as follows[5]

$$
\begin{aligned}
P & =i \times e \\
& =I_{m} \cdot \sin \omega t \times E_{m} \cdot \cos \\
& =1 / 2 I_{m} \cdot E_{m} \sin \omega t
\end{aligned}
$$

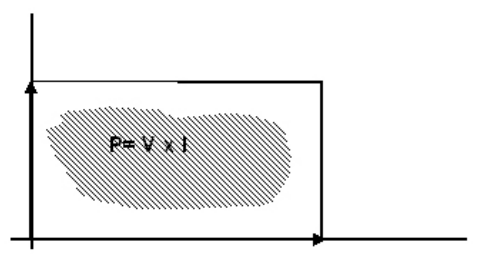

Fig.1. Direction of electric current flow.

$$
\mathrm{P}=\mathrm{V} . \mathrm{I}
$$

In Figure 2 also shows that the curved line w $(\mathrm{P})$ is a sine line with a peak price:

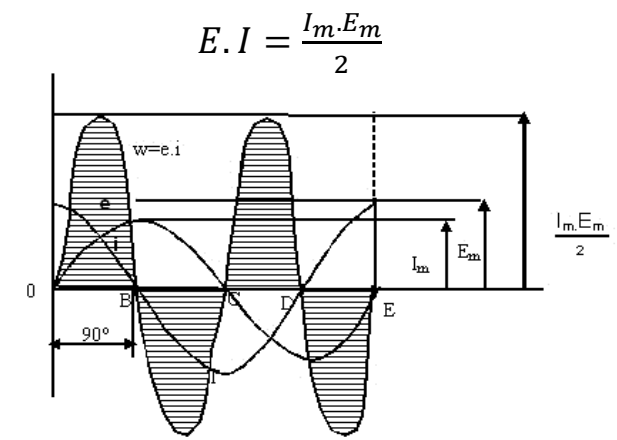

Fig.2. Illustration of voltage and current

\subsection{Active Power or Real Power (Watt)}

Active power or real power is the power used to actually do energy, for example, heat energy, light energy, mechanic energy and so on.The active power unit is Watt.[6]

$$
\begin{aligned}
& \mathrm{P}=\mathrm{V} . \mathrm{I} . \operatorname{Cos} \varphi \\
& \mathrm{P}=3 . \mathrm{VL} \cdot \mathrm{IL} \cdot \operatorname{Cos} \varphi
\end{aligned}
$$

This power commonly used by consumers and converted into work. 


\subsection{Reactive Power}

Reactive power is the amount of power needed for magnetic field formation. From the formation of a magnetic field, a magnetic field flux will form. Examples of power that causes reactive power are transformers, motors, incandescent lamps and so on. The reactive power unit is Var.[7]

$$
\mathrm{VAR}=\mathrm{E} \times \mathrm{I} x \sin \varphi .
$$

\subsection{Power Triangle}

The power triangle is a triangle that describes the mathematical relationship between different types of power (Apparent Power, Active Power and Reactive Power) based on the principle of trigonometry.[8]

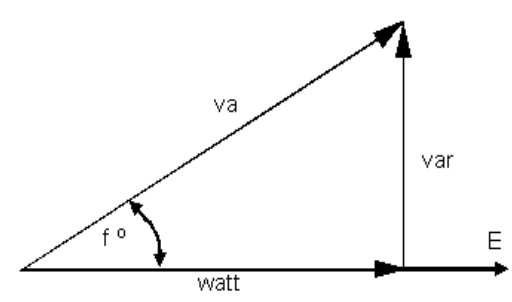

Fig.2. Power triangle

The efficiency of electric power usage is influenced by many factors, including electrical power quality. Electrical power quality is strongly influenced by the use of certain types of loads which result in an efficiency decrease. In this research, household electrical control system was made by using the RLC circuit to reduce the flow so that the home electricity distribution is more efficient[9].

\section{Experimental Detail}

This research was use experimental method. Beginning with gathering information on the design of the electrical control system and understanding it. The research flow chart as shown in Figure 4 and the circuit are shown in Figure 5. 


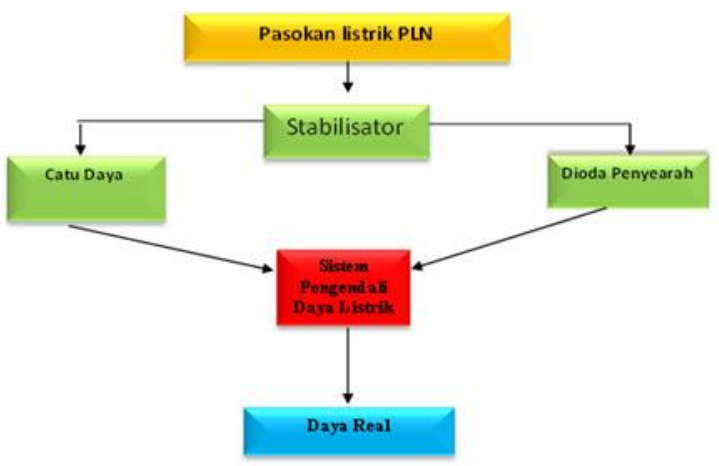

Fig.4. Experimental flowchart.

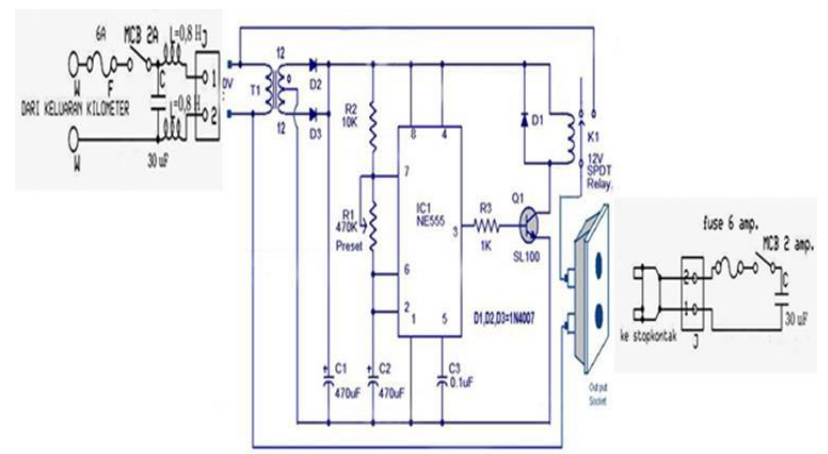

Fig.5. Electric control system circuit.

\section{Result and Discussion}

This research was carried out at Yogyakarta Kertonegaran Guesthouse. Wisma Kertonegaran is a boarding house consisting of 50 rooms with a home electric power of 1300 VA.

Step 1. Arranging components based on the circuit in Figure 5. The results are shown in Figure 6. 


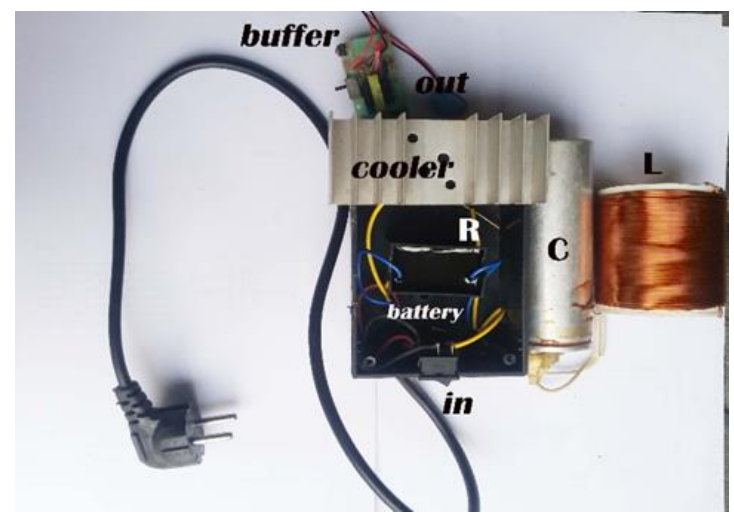

Fig.6. Electrical control device.

Step 2. Installing an electrical controller on the MCB as shown in Figure 7.

Step 3. Calculating the electrical power.

After the device is installed as shown in Figure 7, then it was used to calculate how much the electricity is used before and after the electrical controller is installed. The device is installed for 30 days and the amount of electricity per kwh must be paid as shown in Table 1 .

Tabel 1. Results of the electrical load power at Wisma Kertonegaran.

\begin{tabular}{|c|c|c|c|c|c|c|c|c|c|}
\hline No & $\begin{array}{l}\text { Peralatan } \\
\text { Listrik }\end{array}$ & $\begin{array}{c}\mathrm{P} \\
\text { (Watt) }\end{array}$ & $\stackrel{\mathrm{t}}{\mathrm{t} a \mathrm{~m})}$ & $\begin{array}{c}\text { n } \\
\text { (buah) }\end{array}$ & $\begin{array}{c}\mathrm{W} \\
(\mathrm{kwh})\end{array}$ & $P_{e f(W a t t)}$ & $\begin{array}{c}\mathrm{W}_{\mathrm{ef}} \\
(\mathrm{kwh})\end{array}$ & $P_{\text {real}}($ watt $)$ & \begin{tabular}{|l}
$\mathrm{W}_{\text {real }}$ \\
$(\mathrm{kwwh})$ \\
\end{tabular} \\
\hline 1 & Lampu & 20 & 5.00 & 5 & 0.500 & $(20.0 \pm 0.5)$ & 0.5000 & $(15 \pm 0.4)$ & 0.3750 \\
\hline 2 & Televisi & 100 & 5.00 & 1 & 0.500 & $(80.0 \pm 0.4)$ & 0.4000 & $(50 \pm 0.2)$ & 0.2500 \\
\hline 3 & Setrika & 300 & 0.25 & 1 & 0.075 & $(300.0 \pm 0.3)$ & 0.0750 & $(50 \pm 0.2)$ & 0.0125 \\
\hline 4 & $\begin{array}{l}\text { Mesin } \\
\text { cuci }\end{array}$ & 300 & 0.25 & 1 & 0.075 & $(250.0 \pm 0.5)$ & 0.0625 & $(80 \pm 0.4)$ & 0.0200 \\
\hline 5 & \begin{tabular}{|l|} 
Lemari es \\
2 pintu
\end{tabular} & 120 & 24.00 & 1 & 2.880 & $(100.0 \pm 0.4)$ & 2.4000 & $(60 \pm 0.2)$ & 1.4400 \\
\hline 6 & Laptop & 50 & 1.00 & 1 & 0.050 & $(50.0 \pm 0.2)$ & 0.0500 & $(25 \pm 0.2)$ & 0.0250 \\
\hline 7 & $\begin{array}{l}\text { Rice } \\
\text { cooker }\end{array}$ & 395 & 6.00 & 1 & 2.370 & $(77.0 \pm 0.2)$ & 0.4620 & $(50 \pm 0.4)$ & 0.3000 \\
\hline 8 & $\begin{array}{l}\text { Pompa } \\
\text { air/Sarnyo }\end{array}$ & 100 & 0.25 & 1 & 0.025 & $(250.0 \pm 0.5)$ & 0.0625 & $(60 \pm 0.2)$ & 0.0150 \\
\hline$?$ & & 1385 & 31.75 & 12 & 6.475 & $(1127.0 \pm 0.4)$ & 4.0120 & $(390.0 \pm 0.3)$ & 2.4375 \\
\hline
\end{tabular}

In table 1 it can be seen that the amount of electricity bills for 30 days ( 1 month) before the use of electric control devices is $30 \times 4.0120 \mathrm{kwh} \times 1467.28 \mathrm{Rp} / \mathrm{kwh}=\mathrm{Rp} 176,601.82$ and after using the device is $30 \times 2.4375 \mathrm{kwh} \times 1467.28 \mathrm{Rp} / \mathrm{kwh}=\mathrm{Rp} 107,294.85$. So it can be seen that using the KENDIL device can save electricity costs by Rp 69,306.97 per month. 


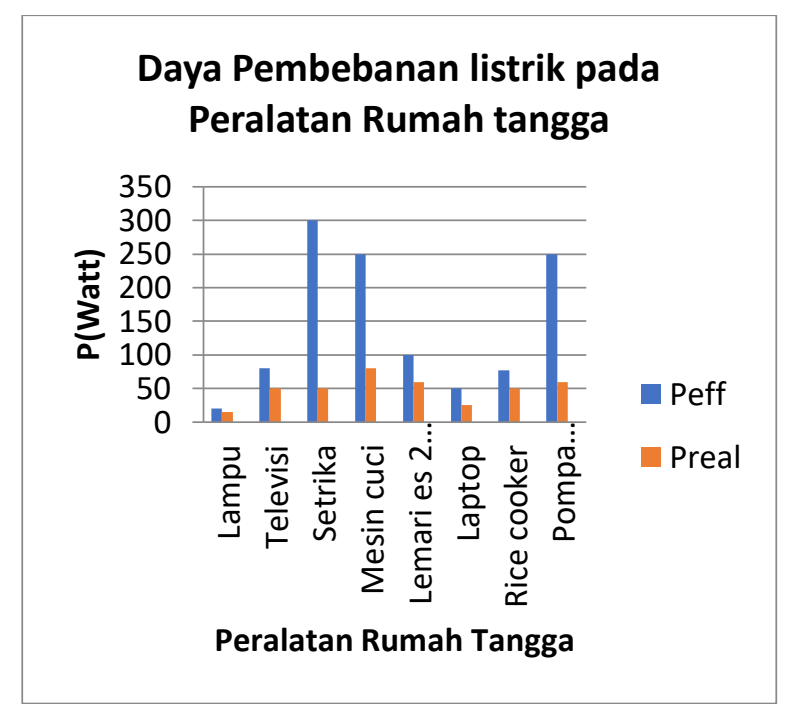

Fig.7. Graph of the load power of household electrical device.

So that the electricity bill using the KENDIL has a ratio of

$$
\frac{P_{e f}}{P_{\text {real }}}=0,6
$$

in other words, the amount of electricity bills per month is $60 \%$ more efficient. This is because the electrical control system (KENDIL) was able to reduce the wasted heat energy or the device is able to reduce leakage current. The existence of a full wave diode in the KENDIL circuit makes voltage stability maintained because energy can be stored in the installed power supply. Therefore, KENDIL can increase the load power of household electrical device and can save on monthly electricity bills as shown in Figure 7 and equation(7).

\section{Conclusion}

An electric control device (KENDIL) is produced by using the RLC circuit to reduce the flow so that the home electricity distribution is more efficient. This device can save $60 \%$ on electricity bills.

Acknowledgments. This work was supported by UST and Wismakertonegaran. Therefore, researchers would like to thank for their trust. 


\section{References}

[1] IEA, "Key World Energy Statistics, OECD/IEA.," 2017. [Online]. Available: www.iea.org/publications/freepublications/publication.

[2] IEA, "World Energy Outlook 2016, OECD/IEA," 2017. [Online]. Available: www.worldenergyoutlook.org/publications/weo-2016/ (accessed in June3, 2017) (2016b).

[3] IEA, "Energy Efficiency Indicators (database), OECD/IEA,” 2017.

[4] I. Nur and A. Arief, . PengembanganSistem Monitoring ListrikRumahBerbasis Cloud Computing. Departement of Electrical Engineering. solo, 2011.

[5] A. P. Schuetze, W. Lewis, C. Brown, and W. J. Geerts, "No TitleA Laboratory on The Four-Point Probe Technique. Am. J. Phys,” pp. 149-153, 2004.

[6] B. M, J. M. Oliver, and Cage, No TitleElectroncs Measurement and Instrumentation. Mc Graw-Hill Kogukusha. Tokyo, 1971.

[7] A. et al Fanny, No TitleRancang Bangun Sistem Kontroldan Pemonitoran Lampu Rumah dengan Smart Phone Android Berbasis SMS Gateway Mikrokontroler ATMEGA16. Pontianak, 2015.

[8] Melipurbowo, No TitlePengukuran Daya Listrik Real Time dengan Sensor Arus ACS. Semarang, 2016.

[9] M. Manuel, A. F. Guisseppi, and N. D. G. Jatinder, No TitleDicision Making Support Systems : Achievements, Trends and Chellenges for the New Decade. London: Edea Group Publishing, 2003. 